\title{
金型加工用切削工具を使いこなす技術課題* \\ Technical Requirements for Fully Utilizing Cutting Tools in Mold and Die Profile Machining
}

\section{星 鐵 太郎** \\ Tetsutaro HOSHI}

Key words : mold and die profile machining, copy milling, NC milling, 3-d CAM software, machining curved surface

\section{1. まえがき}

金型の製作には種々な加工方法が組み合わせて用い られており，切削加工による割合が依然として最も大 きく，続いて放電加工（ワイヤカットも含む）が多用 されている．切削加工の能率と精度の向上は高性能な 切削工具が実用化されてきたこと，それを可能とする 工作機械の性能向上, 加工上の進んだノウハウの蓄 積, NC 加工に打いては計算機ソフトウェアの開発実 用による所が大きい、本稿は金型加工の 中でも，とくに曲面部分の加工を行う， いわゆる型面加工の工程を主題とし，近 年の切削工具の動向をもととして，高性 能切削工具の持つ能力を, 刚先の久け （チッピング）などのために無為に終わ らすことなく現実に発揮させるための， いわゆる使いこなす技術，とくに工作機 械と加エソフトウェアに要求される技術 課題について解説する.

\section{2. 金型の種類}

用途，大きさ，精度，材質ともに多岐 にわたって招り，表 1 中の例光ば板金ブ レス型では，かたや成形品の寸法がメ一 トルオーダのボディ型から，小は十数 $\mathrm{mm}$ のリードフレーム型まである. プラ

* 原稿受付 平成元集 2 月 14 少

** 正会員 豊橋技術科学:大学（豊橋讯天 伯町䒚"雲隹ケ乎 1-1)
スチック型の多くは, 数百 $\mathrm{mm}$ の成形品を対象とす るが，最大高さ $R_{\max } 0.1 \mu \mathrm{m}$ オーダの表面粗さむで 磨きあげる鏡面仕上が必要とされるものが多い。一 方, 熱間用の鍛造型では $R_{\max }$ 数十 $\mu \mathrm{m}$ の粗さで, $0.1 \mathrm{~mm}$ オーダの形状精度がでていれば切削加工のま まで十分なものもある。

鋳鉄（FC 25 など）や構造用炭素鋼（S 55 C など） の比較的切削しやすい材料を素材とする金型もある が，合金鋼，工具鋼，ステンレス鋼など難削性の素材 表 1 金型の用途と材料の代表例

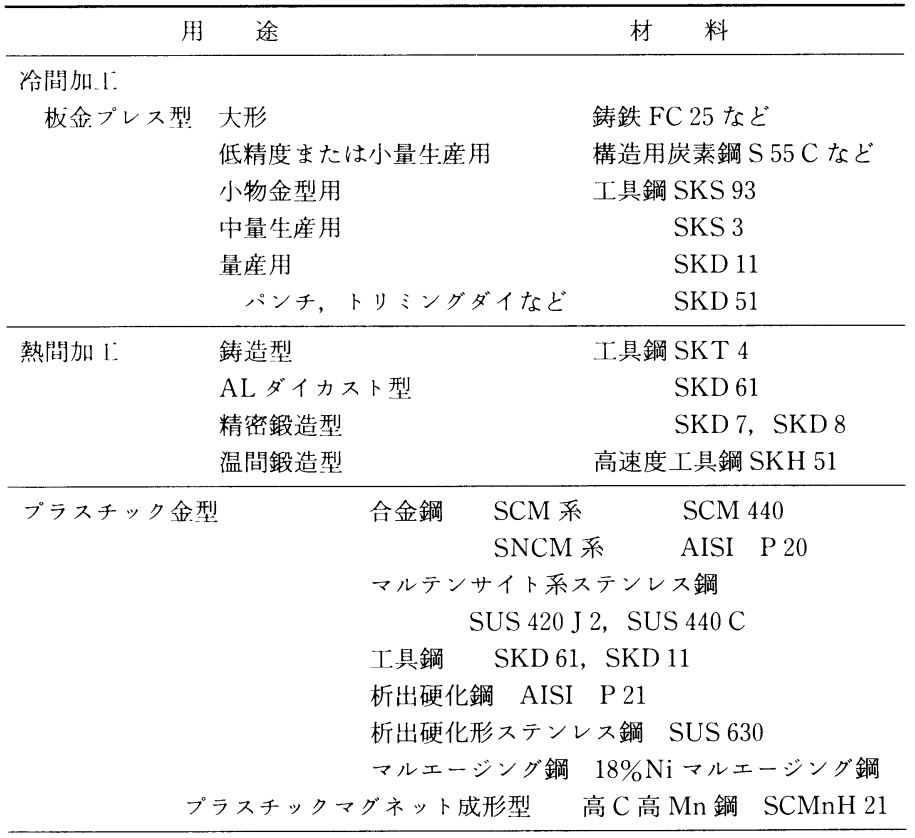


を切削加工しなければならない場合が多い，焼きなら し状態で粗加工し，焼入れ焼戻し後に仕上加工を行ら 場合と，加工前侄処理を施して HRC 30〜45 程度 の硬さにして・(プリハードンと呼ばれている）打いて 切削加工する場合がある。

\section{3. 金型製作の達成目標と加工方法の選択}

多数の金型を製作する期間を含めて，開発期間の短 いことが新製品をタイムリ一に市場に出して成功を収 める要因となる，そのため，金型製作の達成目標とし ては所要期間の短いこと;すなおち短納期が最優先さ れることが多い。続いて高精度・高品質，それから製 作コストの低隇，とくに製作作業の自動化がとり上げ られるのが本来の順序である.

フライス加工を主体とする切削加工が，放電型彫り 加工 (EDM) と競合して型面加工で用いられている. 放電型彫り加工は，逆形状に製作した銅，銅合金また はグラファイト電極を用い，液槽中で放電によって金 型材料を徐々に除去し，電極形状を転写する加工法 で，加工時間は長くかかるが自動化されて抢り，硬質 材料子加工できる，切削加工では難しい狭く深い凹み (プラスチック金型の深リブと呼ばれる部分) や，半 径の小さな隅の加工がでさるなどの特徽のため，広く 用いられている，液膜を介した放電の替わりに，電解 溶液を介した通電に伴う電気分解の原理による電解型 彫り加工（ECM）もおずかではあるが，鍛造型など に実用例がある。

フライス加工による曲面形状の切削には，做いフラ イス加工と NC（数值制御）フライス加工がある。倣 いフライス加工は，他の方法で製作したモデルを倣っ て, ボールェンドミル等の切削工具により金型素材を 切削する方法で, 古くから型面の粗加工に用いられて いた. 1977 年以降, 切削性能の高い超硬ボールェン ドミルが実用されるようになったのに伴い，能率と加 工精度の優れた做いフライス盤が開発され，仕上加工 にも広く用いられる主要な加工法となっている， NC フライス加工は，曲面加工動作指示する $\mathrm{NC}$ 指令 をコンピュータを用いて作成し， NCフライス盤また は多くの場合マシニングセンタによって型面加工を行

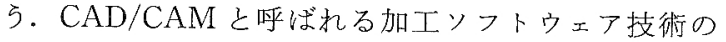
進歩に伴ってかなり広く行われるようになったが，そ の技術は現在をだ急速な発展途上にあり，本文に揭げ るような技術的課題の達成によって，今後一層の展開 が期待される加工法である.

どの加工法をとるかは，総合した製作期間の長短が 大きな決定要因となっている.ここで「総合した」と

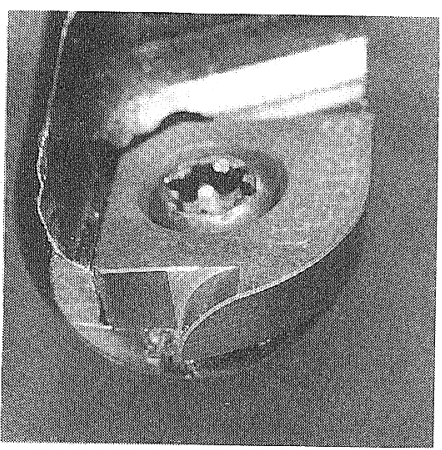

直径 $20 \mathrm{~mm}, 1$ 枚刃スローアウェイ式超硬ボール エンドミル

図 1 円弧状中心切れ刃を持つボールエンドミルの瀜状 对先形状

言らのは，工程自体の所要時間の活かに，倣いフライ スではモデルの製作， NC フライスでは $\mathrm{NC}$ 指令の準 備，放電型彫りでは電極の製作を含み，またフライス 加工で細かい仕上面粗さまで仕上切削をしておけば， 後工程の手仕上の時間が短縮されるとか, 放電型彫り の仕上面は表面の硬化層があるために手仕上に長時間 を要するなどの要因が考慮されるためである.

\section{4. 金型加工用切削工具の進歩}

\section{1 新刃形ボールエンドミル}

切削加工に上る型面加工に高能率をもたらするか けとなったのは1977年に実用化された中心部に円弧 状切れ刃をるつ新冈形の超硬ボールェンドミルの登場 であった，超硬合金を刃先とする切削工具は第 2 次大 戦中から使用され，国内では戦後に広く普及したこと は周知の通りであるが，ボールェンドミルについて は，切削速度がゼ口に近くなる中心部の切れ刃に欠損 （チッピング）が生じるため，鋼材に対して䖵超硬合 金が使用できず，高速度工具鋼（HSS）の及が使用 されていた。

図 1 の写真に見るような，中心部の切れ刃を円弧状 の渦巻形状とすることによって，中心部切れ刐に欠損 を起こさずに円滑な切削を行わせることができる、図 2 の連続写真に見るように, 1 片の切りくずが生成さ れる切削サイクルは, 中心部切れ刃がまず切削を終わ り(写真 3 ), 切削速度の高い外周切れ刃が最後要で 切削を続けて切りくずを外側に投げ出すようにして終 了寸る（写真 4）ため切りくず離れがよく，切れ刃の 欠損が起こりにくい゙. この工具の実用により超硬工 具による曲面形状の高能率・高精度加工の可能性が高 ぬり, 新技術の開発が相次いで今日に至り，まだ多く が今後の課題として残されている. 

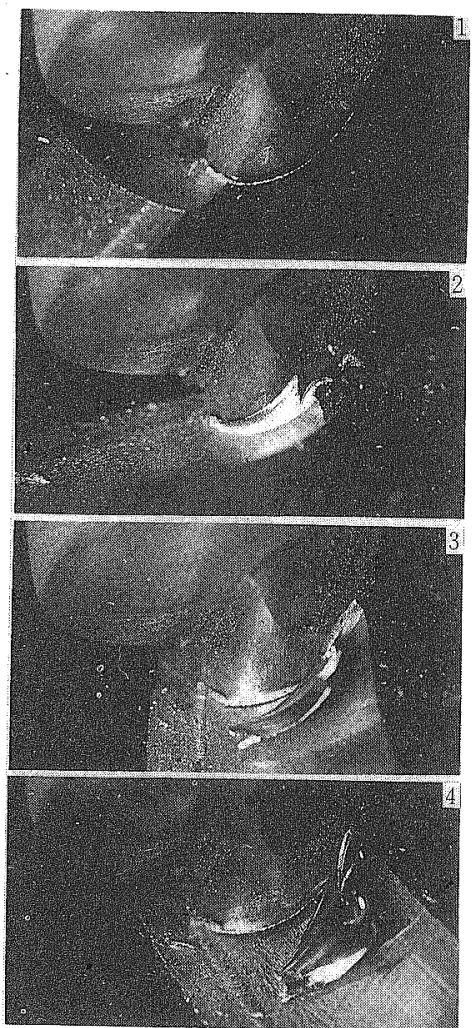

工具直径： $30 \mathrm{~mm}$, 回転数 : $1000 \mathrm{rpm}$, 被削材: S $45 \mathrm{C}$, 送り: $600 \mathrm{~mm} / \mathrm{min}$, 切削幅： $17 \mathrm{~mm}$, 軸方向切込み： $3 \mathrm{~mm}$, ダウンカット

図 2 円弧状中心切れ为1枚间超硬ボール エンドミルによる切削サイクルの ストロボ連続写真(細井ら ${ }^{11}$ 上り)

4.28 角形チップェンドミル（スローアウェイ式） 新邓形ボールエンドミルに用いられたような凸曲面 すくい面の優れた切削性能は，それ以前からあった千 鳥冈サイドカッタにも例を見ることがでさる2). 型面 加工用に近年上く用いら机るよらになった 8 角形チッ プのスローアウェイ式ェンドミルにも図3の写真に見 るような凸すくい面の応用がなされたものがある。従 来から㘯る8 角形チップのすくい面外周在頂角が大き い円すい面に修正することによって凸すくい面とし， 切削性能を向上している。图 4 に示すように8 角形 チップのスローアウェイエンドミルは, 半径方向に送 る平削り（A 及び B）の㹬かに，軸方向飞送るドリ ル加工 (C), ドリル加工に引き続く平削り加工，雕 り込んだポケット内の肩削り (D), 斜め下に送るラ ンピング加工（E）ができる．型面の粗加工で大きな 工具径（30 mm 以上）を用いる段階ではボールェン
図 3 凸すくい面を持つ 8 角形 チップスローアウェイ式 非球面エンドミルの阵先 形状
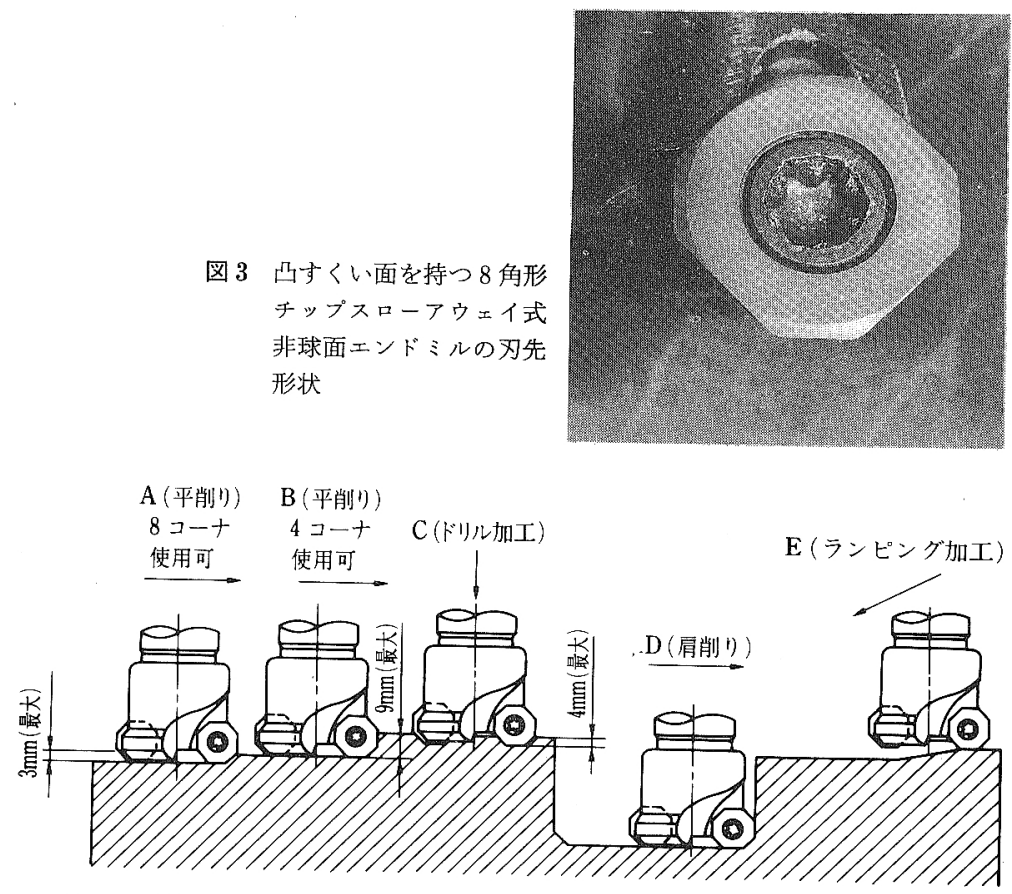

角形スローアウェイチップ非球面エンドミルによる各種粗加工の説明図 (新井：深切込みエンドミル/ボールエンドミル/多機能工具 ${ }^{3)}$, p. 49 による)

ドミルよりも高能率加工のできる非球面工具の一つと して有効である. また，カッタの回転に加壳て公転円 運動の送りを行わせながらへリカル状にランピング加 工寸れば大径穴の粗加工を高能率に行う工具としても 有効である.

\section{3 その他の金型加工用切削工具}

詳細は業界誌等（例点ば文献 3)）にゆずるとして, 工具メ一カ各社より種々の新工其が出されている。型 面加工用に限って主なものを挙げてみると次の上うな 例がある。

(1) ボールェンドミル

a. スローアウェイ式各種設計

b. サーメットあるいはセラミックチップの併用

c. 超硬あるいは粉末 HSSソリッド（をく）ボー ルエンドミル

d. CBN 刃先ボールェンドミル（鋳鉄型面加工用 岗るいは高硬度型面仕上切削用)

(2) 非球面工具

a. 小径深リブ加工用エンドミル

b. 深切込及用不等权じ机角, スローアウェイエ ンドミル

c. ポケット彫り込久用スローアウェイエンドミル

d. 丸型チップスローアウェイェシドミル 


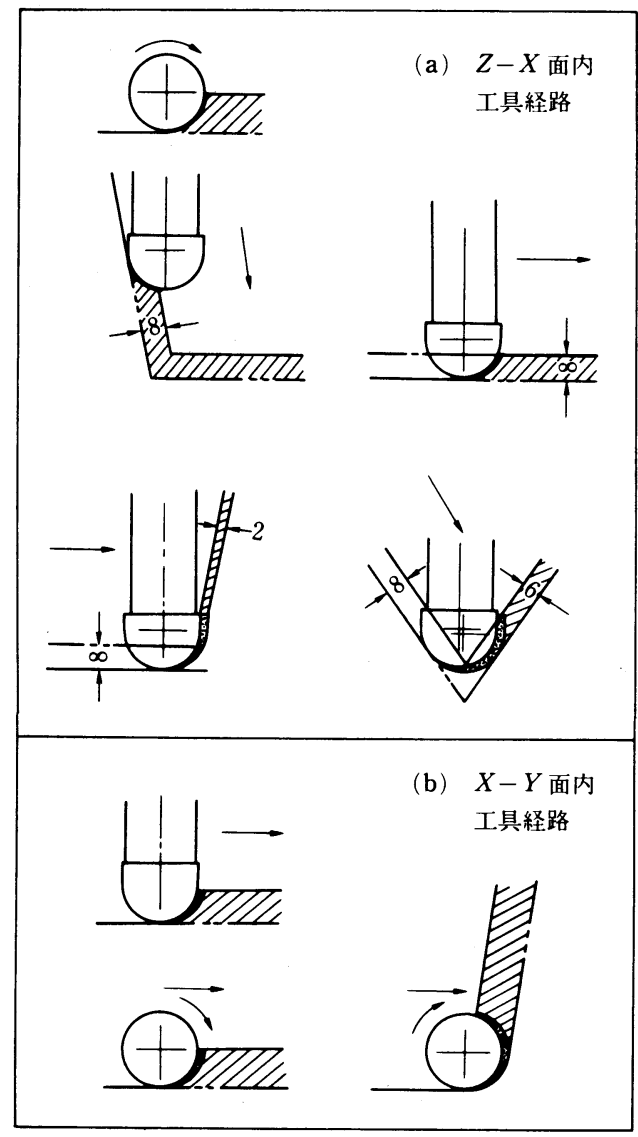

図 5 工具の進行方向による材料除去率 (MRR) の变化 の説明例（直径 $25 \mathrm{~mm}$ ボールェンドミル）(細井4) より)

\section{5. 高能率粗加工の技術課題}

切削による型面加工の長所は，とくに粗加工におい ては材料除去率（Material Removal Rate, MRR）を 大きくして，加工時間が短縮できる点であり，短所と しては工具の破損ないしは切れ刃の欠損（チッピン グ）が起こりやすい, フライス加工に特有の振動が起 こることがある，作業の完全な自動化がはかりにくい などがあげられる，短所を補い長所を伸ばすために必 要な技術的課題をあげてみよう.

\section{1 材料除去率（MRR）の一定保持}

工具の破損あるいは切れ刃の欠損は, 工具 1 回転当 たりの材料除去体積が急激に増大して刃先にかかる切 削力とそれに伴ら刃先のたわ亦変位が急増する瞬間に 生じる. 図 5 に見るよらに工具を軸方向（ $Z$ 方向） にも送りながら加工する場合 (a), 軸方向には動かさ ず $X Y$ 平面内で等高線工具経路で加工する場合 (b) のいずれに拈いても, 曲面輪郭の加工に拈いては送り

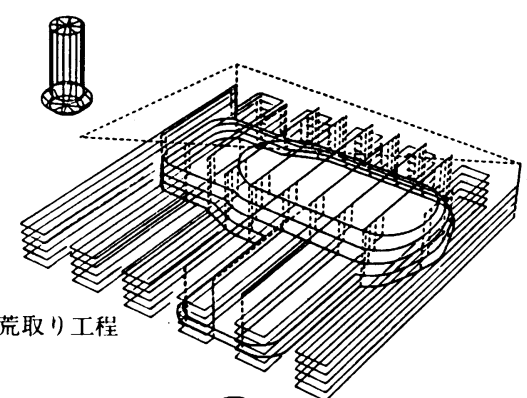

(a) 荒取り工程<smiles>C#[W]#[W]</smiles>

(b) 等高線工具経路

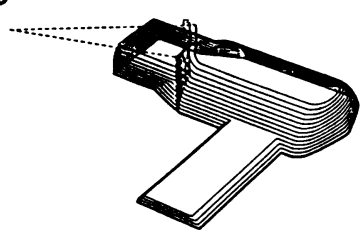

(c) 走查線工具経路

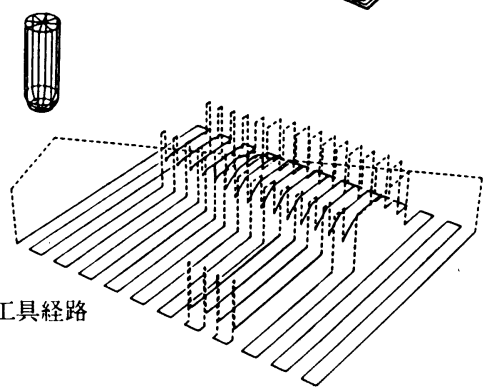

図 6 近似的に MRR一定保持の容易な高能率加工工具経 路の説明図（鈴木ら5)より）

率一定であればMRR は絶えず変動し，とくに工具軌 跡が曲がり觔に達した時には MRR が瞬間的に急増す る. 高能率粗加工の実現のためには, 使用工具と被削 物材質に対して経験的に定めることのできる適当な MRR の上限許容範囲（例えばさきの図 1 に示した円 弧状中心切れ刃ボールェンドミルで S 45 C 鋼切削の 場合は 30〜 $\left.35 \mathrm{~mm}^{3} / \mathrm{rev}\right)$ を常に保つよう加工を行ら ことが必要である.

MRR一定保持の条件を近似的にではあるが容易に 実現できる工具経路の要点として，円弧状中心切れ闭 ボールエンドミルの発明者による著書(5) には次の 3 点 が説かれている.

（1）切削中に工具を軸方向（Z 軸方向）にはなる ベく動かさない，従って平らな素材面に対して最 初に行ら荒取りエ程に拈いてはカッタ（高能率の ため非球面工具を用いる）がある高さの平面上を 移動しながら加工を行い，図 6 (a)に見るように その高さより上の不要部分を全部削り終わってか ら，切込み分だけ軸方向に移動して次の高さの平 


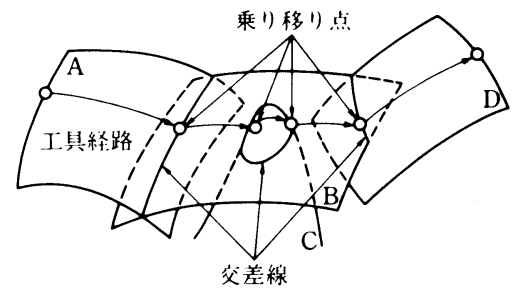

図 7 複合曲面 (要素曲面 A, B, C, D の組合せで与えられ ている）に対する連続乗り移り工具経路の説明図

面にかかるようにする.

（2）荒取り後の曲面を中仕上するには，球面工具 （ボールェンドミル）によってまず図 6 (b) に示 すような等高線工具経路により加工する。 このと きダウンカットが行われる方向に送り運動を行 い, アップカットの状況を極力避ける.

（3）走査線工具経路は必然的に軸方向移動を伴ら ので，図6(c)に見るよ5に傾斜が例えば $45^{\circ}$ （この角度は状況によって変えるが）上り緩い曲 面の頂上部之底面部のみに限って行う。

近年に打ける做いフライス盤の性能向上の課題はこ れら 3 項目に対応する工具経路を高速でも安定して做 い動作できるよらな倣いサーボ装置を実現することに あった。 また NCフライスによる場合には，複数の 要素曲面を組み合わせて与えられた曲面形状（複合曲 面と呼ばれる）に対して，图７に示すように要素曲面 間の交差線上で次の要素曲面に連続的に乗り移って行 くような加エソフトウェアの研究がすでに行われてい $ろ^{5}$.

さて, 上記 3 点に従う工具軌跡においても, 送り率 を一定にする限りは急な曲がり觔に打ける MRRの急 増を避けることはできない，送り駆動機構に適応制御 を組み込んで送り速度の自動調整を行うのが一つの解 決方法である. 今後の課題としてコンピュータ上でシ ミュレーションを行いMRRの一定保持が行われるよ らな送り率を求めて NC 指令を発生する機能が実現 可能となるであろう.

\section{2 振動の抑制}

フライス加工によく出現する振動には，原因の異な る 2 つの種類がある. 一つは再生びびりであり，他方 は断続切削に伴ら切削力の強制的変動による振動であ る. 比較的小径のカッタを用いて行ら型面加工に打い ては後者が問題となることが多い.これは切削力が周 期的に変動し, 強制振動源となって工具・工作物間に 働くことにより，断続の基本周波数あるいはその整数 倍の高調波周波数で発生しらる強制振動である。これ らの周波かいずれかが，機械構造系の振動しやすい
周波数, すなわち固有振動数に近づくと共振して顕著 な振動を生じる. 工具の回転数をわずかだけ調整する ことにより，共振を避けて振動を抑制することができ るはずである. しかし, 型面加工に颃いては送り方向 が絶えず変化するので問題となる固有振動数が単一で はなく, 時間と共に移り変わるので, 振動を常時監視 し, 自動的に主軸回転数の微調節を行うような自動振 動抑制装置の開発が望まれている ${ }^{6}$.

また, 粗加工の高能率化に伴って, 従来の主軸テー パによる工具保持が断続切削に伴う振動と衝撃に対し て，十分に強固ではなくなってきて扔り改良が望まれ ている.

\section{6. 高能率高精度仕上加工の技術課題}

\section{1 高速高精度工作機械}

さきに図 6 に示された (b) 等高線工具経路と (c) 走査線工具経路による加工を, 工具経路の間隔 (ピッ クフィードといら）を十分に細かくして行えば高精度 な仕上面が得られる．NCフライス加工でこれを行ら には 5.1 節で述べたような連続乗り移り機能を持つ加 エソフトゥェアによることが前提であり，また乗り移 り時の干渉チェックと工具半径のオフセット計算が十 分な精度で行われることが必要である。 また，以下に 述べるような細かなピックフィードを用いるため，作 成した NC 指令は膨大な量となり，すべてを記憶媒 体に收めることが経済的に不可能となるので，加工と 実時間に計算処理を進めることが必要である.

中仕上の次に仕上を行う場合，ボールェンドミルの 工具径は中仕上に用いたものの $60 \%$ 前後の小さなも のを選ぶことができる．最終仕上の段階では，曲面間 の交差線の觔に指定された最小半径に対応する工具径 を用いることとなる．プラスチック型の場合，最小工 具径は 3 10 $\mathrm{mm}$ 程度の小さいものをとる必要のある 場合が多いので，工作機械の主軸回転数は控え目に見 ても最高 $6000 \mathrm{rpm}$ 程度の高速性能が求められてい る. 最高回転数で連続長時間の切削を行っても主軸位 置の熱変位が $\pm 0.03 \mathrm{~mm}$ 以内に入る熱安定性が必要 である。

ピックフィードを細かくするほど仕上面の粗さは小 さくなり, 後工程の手仕上の時間が短縮される効果が あるので最終切削仕上に打いては， $0.3 \mathrm{~mm}$ 程度まで 小さくして行いたい場合が多い.ピックフィードを小 さくするに伴い，加工時間の面から高い送り速度が必 要となり当面の目標として $6000 \mathrm{~mm} / \mathrm{min}$ の同時 3 軸 連続経路送り速度で $\pm 0.03 \mathrm{~mm}$ の輪郭精度を保証し たい. NC 工作機械の場合には工具軌跡の補間計算を 
表 $2 \mathrm{NC}$ フライス加工による仕上加工の高速・高精度性能の達成目標

\begin{tabular}{|c|c|c|c|c|c|}
\hline & $\begin{array}{c}\text { 実用的 } \\
ヒ^{0} ッ ク \\
フ ィ ー ト ゙ \\
(\mathrm{~mm})\end{array}$ & $\begin{array}{l}\text { 最高主軸 } \\
\text { 回転 } \\
\text { (rpm) } \\
\end{array}$ & $\begin{array}{l}\text { 連続送り } \\
\text { 速度 } \\
(\mathrm{mm} / \mathrm{min})\end{array}$ & $\begin{array}{c}\text { (その時の } \\
\text { 直線補間 } \\
\text { 間隔) } \\
(\mathrm{mm})\end{array}$ & $\begin{array}{l}\text { 精度 } \\
(\mathrm{mm})\end{array}$ \\
\hline 現状の代表例 & $1 \sim 0.5$ & 4000 & 1000 & (1) & \multirow{3}{*}{ \pm 0.03} \\
\hline 当面の目標 & $\sim 0.3$ & 6000 & 6000 & $(0.5)$ & \\
\hline 長期的目標 & 0.1 & 10000 & 10000 & $(0.3)$ & \\
\hline
\end{tabular}

とができる，常にこのような傾きを保つよう な同時 5 軸制御の $N C$ フライス加工の開発 が一つの技術課題である。これはXYZ3 軸 方向の直線移動に加えて A (X 軸回り) と B（Y軸回り）両軸の回転送りを備えた工作 機械と, 同時 5 軸の $\mathrm{NC}$ 指令を発生し, 主 軸端とチャック及び工具が他と干渉しないこ

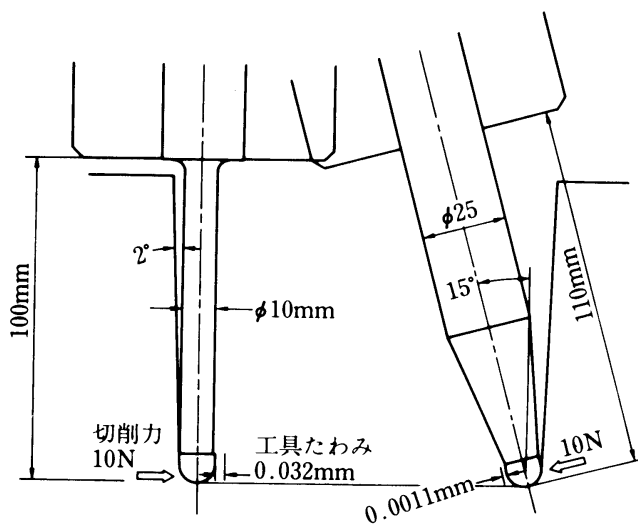

(a) 同時 3 軸制御
図 8 切り立った壁の仕上加工における工具たわみによる 加工誤差発生の説明例（a）図と，同時 5 軸制御に よる抑制の方法（b）図

行ら間隔を大きくとれば高速送りは可能であるが，そ れを十分に細かい間隔（例えば $0.5 \mathrm{~mm}$ ) で行らに は，高速な計算処理機構を備えなければならないとい ら技術課題がある.

現状の NC フライス加工では，表 2 に示すように これら性能が達せられない場合が多く，上記の数字は 当面の達成目標であり, 長期的には表の下欄に示すさ らに高速性能を目指す必要があろう。

金型加工用切削工具にもスローアウェイ工具が一般 化した今日, 主軸の内部を通して（スルースピンド ル）空気を送り，工具刃先を冷却する機能が強く望ま れている.これは工具寿命の延長と切りくずの排出に 効果があり，スローアウェイ工具の締付けねじが固く 締まり過ぎて分解できなくなるのを防ぐのに必要であ る. また，同じ機械で高能率ドリル加工を行う場合の ためにスルースピンドルの切削液供給も行える設計が 望ましい。

\section{2 工具たわみの抑制}

切り立った壁の根元の觔を小径工具で仕上加工する 場合, 図 8 (a)のように生じる工具たわみによる加工 誤差は, 切削加工にとって最も困難な問題である. 図 8 (b) に示すよ $5 に 15^{\circ}$ 程度工具を傾斜させて加工す れば, 根元の太い工具を使用でき，この誤差を防ぐこ
とを検証する加エソフトゥェアを必要とする.

も5一つの可能な方法としては 5.1 節に述べた MRRの計算シミュレーションによって工具刃先のた わみとその方向を計算によって求め，その䛊差分を補 正した NC 指令を発生する機能が実現できるであろ 5 .

\section{7. 結 言}

近年に怙ける金型用切削工具の進歩は型面加工に括 ける切削技術の重要性を高め, 做いフライス盤の性能 向上と NCフライス盤あるいはマシニングセンタに よる曲面加工技術の向上, とくに金型 $\mathrm{CAD} / \mathrm{CAM}$ 加 エソフトゥェアの発達を促してきた. 今後に打ける技 術課題として, 工作機械に扣いては高速高精度性能, 送り速度の適応制御，振動の自動抑制制御，スルース ピンドル空油供給ならびに工具保持強度の強化が必要 であり，また同時 5 軸制御の NC 機械が検討される べきである。また，金型 CAD/CAM 加エソフトウェ アの今後の進展には多くの重要課題があり, 工具経路 発生にかかわる CAM 部分にだけ限定しても, 複合曲 面に対する連続乗り移り，正確な干渉チェック，非球 面工具に対する工具オフセット，荒取り工程・等高線 工具経路・走査線工具経路の実時間自動発生, シミュ レーションによるMRR一定保持と工具たわみの補正 制御などが望まれている。 また，同時 5 軸制御による 曲面加工のソフトウェアも必要な課題である.

\section{参考文献}

1）細井俊明, 星 鐵太郎：5ず巻状刃先をもつボールエン ドミルの切削作用，日本機械学会論文集，44，378（1978） 722.

2）加工技術データファイル，(財)機械技術振興協会技術研 究所（1978） 704 D 32-02, 1-2/2.

3）最近の金型用切削工具の技術動向，型技術，3，12（1988） 17.

4）細井俊明：新しい金型型面加上法-Hosoi 式型彫り法 と加工例，日刊工業新聞社（1983）。

5）鈴木 裕, 山崎和雄, 星 鐵太郎, 黒宮義久：金型実時 間加工用数值制御システムの開発 (第 2 報), 精密工学会 誌, 53, 12 (1987) 1952.

6）星 鐵太郎，吉原 篤，中村公…搌動抑制のためのフ ライス加工適応制御システムの開発, 昭和 62 年.度精密工. 学会春季大会学術講演会講演論文集 C (1987) 75. 